\title{
A case of ARF after chromopertubation with povidone iodine
}

\author{
Savita S. Gautam ${ }^{1 *}$, Rajesh S. Gautam ${ }^{2}$ \\ ${ }^{1}$ Department of Obstetrics and Gynaecology, Mark Hospital, Bilaspur, Chhattisgarh, India \\ ${ }^{2}$ Department of Nephrology, Mark Hospital, Bilaspur, Chhattisgarh, India
}

Received: 08 May 2018

Accepted: 30 May 2018

\section{*Correspondence:}

Dr. Savita S. Gautam,

E-mail: drsavita_gwl@yahoo.co.in

Copyright: $\odot$ the author(s), publisher and licensee Medip Academy. This is an open-access article distributed under the terms of the Creative Commons Attribution Non-Commercial License, which permits unrestricted non-commercial use, distribution, and reproduction in any medium, provided the original work is properly cited.

\begin{abstract}
Povidone iodine is a widely-used antiseptic agent, especially for cutaneous lesions. Despite its apparent innocuousness, some cases of acute renal failure are reportedly due to iodine toxicity. Authors report a case of an acute renal failure secondary to povidone iodine exposure in a 22-year-old woman. She underwent a hysteroscopy for diagnosis of secondary sterility with bilateral tubal block in hysterosalpingogram, and povidone iodine was used as the contrast agent. She developed acute renal failure with oliguria, later on anuria during the postoperative period. Treatment with diuretics and hemodialysis led to a favourable outcome and return of normal kidney function. Mucosal administration of povidone iodine appears to lead to greater iodine toxicity than cutaneous administration. The clinical feature of this patient suggested tubular necrosis caused by iodine, after the other possible causes of acute renal failure were ruled out. Acute renal failure secondary to povidone iodine administration is possible, especially through mucosal surfaces. Outcome is favourable after the conclusion of exposure and symptomatic treatment.
\end{abstract}

Keywords: Germ cell tumors, Mature cystic teratoma, Urothelial carcinoma

\section{INTRODUCTION}

Povidone-iodine is a broad-spectrum antiseptic applied topically to treat wounds and prevent their infection. Its active ingredient, iodine is effective against yeasts, molds, fungi, viruses, and protozoans; in the form of the $\mathrm{H} 2 \mathrm{OI}+$ cation, it also acts against bacteria by breaking down their cell membrane proteins. ${ }^{1}$ Consequently, povidone-iodine is widely used as a surgical scrub, for preoperative and postoperative skin cleansing, and for the treatment of wound infections and burns. It can also be used in pleurodesis for malignant pleural effusions, in percutaneous transcatheter sclerotherapy of lymphoceles occurring after kidney transplantation (a well-known surgical complication), and as a contrast agent. However, several cases have been reported of acute kidney injury (AKI) due to iodine toxicity. AKI has been recorded in a patient who underwent hysteroscopy for diagnosis of primary sterility using povidone-iodine as the contrast agent. ${ }^{2}$ In one case, AKI developed in a patient who attempted suicide by ingesting iodine tincture, in burn patients treated topically with povidone-iodine, in a kidney allograft recipient with recurrent lymphoceles treated with povidone-iodine instillations, and in patients undergoing mediastinal irrigation with povidone-iodine. ${ }^{3-}$

8 Some cases were accompanied by increased serum iodine concentration. Herein, authors report a case of acute renal failure in patient underwent hysteroscopy for diagnosis of secondary infertility using povidone iodine for chromopertubation.

\section{CASE REPORT}

A 22yrs old patient underwent for diagnostic laparoscopy and hysteroscopy for secondary infertility as her hysterosalpingogram was showing bilateral tubal 
blockage. Her preoperative findings showed bilateral fimbrial ends were coagulated, fimbrioplasty was done on left side followed by chromopertubation with betadine free spillage was seen on left side, right sided tube appeared blocked so minilaparotomy done followed by right sided fimbrioplasty, betadine was used for chromopertubation. Post operatively patient had dark coloured urine and after that developed oliguria, for which nephro consultation done, on advice of nephrologist renal function done on post op day 1 and serum creatinine was found $3.72 \mathrm{mg} / \mathrm{dl}$, hemodialysis done.

On post op day 2 she developed fever, her laboratory data revealed haemoglobin $9.8 \mathrm{gm} / \mathrm{dl}$, total leucocyte count was $19100 / \mathrm{cmm}$, her liver function teat showed SGOT84u/l rest was within normal limit, malaria parasite was found negative and lactate dehydrogenase $3068 \mathrm{u} / \mathrm{l}$ that was remarkably raised. Ultrasound examination revealed increased size of both kidneys and prominent medullary hypoechogenicity, compatible with a diagnosis of acute kidney injury. On post op day 3, her haemoglobin was $8.9 \mathrm{gm} / \mathrm{dl}$ and peripheral smear showed haemolytic anemia with neutrophilic leukocytosis with thrombocytopenia, test for G6PD deficiency was normal, her indirect coombs test was normal, on post op day 4 her hemogram showed haemoglobin $7.8 \mathrm{mg} / \mathrm{dl}$, total leucocyte count $9800 / \mathrm{cmm}$, her renal function test revealed serum creatinine $8.07 \mathrm{mg} / \mathrm{dl}$, she was managed with hemodialysis under nephrologist. At discharge, the patient's serum creatinine levels had fallen to $3.2 \mathrm{mg} / \mathrm{dl}$. One month after discharge, the patient's serum creatinine had dropped further to $1 \mathrm{mg} / \mathrm{dl}$.

\section{DISCUSSION}

Povidone-iodine is a widely used and generally safe antiseptic, sclerotherapy, and contrast agent. However, its absorption into the systemic circulation (e.g., through damaged skin in burn patients or as a result of internal administration for treatment of lymphocele after renal transplantation may lead to toxicity. ${ }^{5,6}$ Povidone-iodine toxicity is generally indicated by increased serum iodine level and usually manifests as AKI, often in the form of tubular necrosis. Indeed, a recent experimental study showed that povidone-iodine exposure induced time- and concentration-dependent apoptosis and necrosis in cultured human epithelial cells and rat oral mucosal tissue. $^{9}$ AKI may be accompanied by metabolic acidosis, anemia, or hypernatremia, this patient presented with AKI and anemia, but showed no definite metabolic acidosis or hypernatremia. ${ }^{3,6,10,11}$

In literature, there are only one report about ingestion of iodine tincture led to increase of aspartate aminotransferase $545 \mathrm{U} / \mathrm{L}$, alanine transaminase $51 \mathrm{U} / \mathrm{L}$ and lactic dehydrogenase of $5563 \mathrm{U} / \mathrm{L}$, in present case aspartate aminotransferase and lactate dehydrogenase was found raised. ${ }^{3}$ Pattern of elevated aspartate aminotransferase compared with alanine transaminase accompanied with increased lactic dehydrogenase might be supposed to be a nonspecific liver injury due to iodine toxicity.

In several previous cases of iodine toxicity, hemodialysis and hydration were sufficient to produce a favorable renal outcome. ${ }^{2,5,6}$ Although no specific treatment for iodine toxicity is available, reversible recovery from AKI may be induced through hemodialysis and/or corticosteroid therapy as deemed appropriate based on kidney biopsy findings.

\section{CONCLUSION}

In conclusion, authors have reported a case of iodine toxicity that was presented with acute renal failure and anemia and recovery occurred after hemodialysis. Therefore, we recommend judicious and indicated use of povidone iodine.

Funding: No funding sources

Conflict of interest: None declared

Ethical approval: Not required

\section{REFERENCES}

1. Hsu YC, Nomura S, Kruse CW. Some bactericidal and virucidal properties of iodine not affecting infectious RNA and DNA. Am J Epidemiol 1965;82:317-28.

2. Beji S, Kaaroud H, Ben FM, Abderrahim E, Zghidi $\mathrm{S}$, Ben $\mathrm{FH}$, et al. Acute renal failure following mucosal administration of povidone iodine. Presse Medicale (Paris, France: 1983). 2006 Jan;35(1 Pt 1):61-3.

3. Mao YC, Tsai WJ, Wu ML, Ger J, Deng JF, Yang CC. Acute hemolysis following iodine tincture ingestion. Hum Exp Toxicol. 2011 Oct;30(10):17169.

4. Lavelle KJ, Doedens DJ, Kleit SA, Forney RB. Iodine absorption in burn patients treated topically with povidone-iodine. Clin Pharmacol Therap. 1975 Mar 1;17(3):355-62.

5. Pietsch J, Meakins JL. Complications of povidoneiodine absorption in topically treated burn patients. Lancet 1976;1:280-2.

6. Manfro RC, Comerlato L, Berdichevski RH, Ribeiro AR, Denicol NT, Berger M, et al. Nephrotoxic acute renal failure in a renal transplant patient with recurrent lymphocele treated with povidone-iodine irrigation. Am J of Kidney Dis. 2002 Sep 1;40(3):655-7.

7. Campistol JM, Abad C, Nogue S, Bertran A. Acute renal failure in a patient treated by continuous povidone-iodine mediastinal irrigation. The $\mathbf{J}$ Cardiovasc Surgery. 1988;29(4):410-2.

8. Ryan M, Al-Sammak Z, Phelan D. Povidone-iodine mediastinal irrigation: a cause of acute renal failure. J Cardiothorac Vasc Anesth. 1999;13:729-31. 
9. Sato S, Miyake M, Hazama A, Omori K. Povidoneiodine-induced cell death in cultured human epithelial HeLa cells and rat oral mucosal tissue. Drug Chem Toxicol 2014;37:268-75.

10. Moudden MK, Labaye J, Sarret D, Cazajous G, Herody M, Didelot F. Acute renal failure following internal administration of povidone iodine: a case report. Rev Med Interne 2007;28:556-8.
11. Hunt JL, Sato R, Heck EL, Baxter CR. A critical evaluation of povidone-iodine absorption in thermally injured patients. J Trauma 1980;20:127-9.

Cite this article as: Gautam SS, Gautam RS. A case of ARF after chromopertubation with povidone iodine. Int J Reprod Contracept Obstet Gynecol 2018;7:2982-4. 